\title{
AFLATOXINS IN MIXED FEEDS FOR RABBITS
}

Adriana Saubois \& Marcelo C. Nepote Microbiology Laboratory. Biotechnology Department, Chemical Engineering Faculty Universidad Nacional del Litoral. Santiago del Estero 2829, 3000 Santa Fe, Argentina.

Key words: Aflatoxins, Aspergillus flavus, mixed feeds, rabbits.

Palabras clave: Aflatoxinas, Aspergillus flavus, alimentos balanceados, conejos.

\section{SUMMARY.}

Ten samples of mixed feeds and one of lucern (alfalfa) were analysed. They were supplied by processing plants from Santa Fe Province, Argentina, and designed for feeding rabbits. Several breeding farms had claimed that these lots were the possible cause of intoxication. The degree and type of fungal contamination and the presence of the following mycotoxins were analysed: aflatoxins (AFI), ochratoxin A, citrinin, penicillic acid, zearalenone (ZEA), and trichothecenes $T-2$ toxin, diacetoxyscirpenol (DAS) and deoxynivalenol (DON). The total fungal count was carried out by the dilution plating method,on dichloran rose bengal chloramphenicol agar (DRBC). Isolation of species was performed bymeans of direct plating on moist chambers as well as the following media: Aspergillusflavus-parasiticus agar (AFPA), chloramphenicol-potato-dextrose agar (PDAC) and dichloran 18\% glycerol agar (DG18). Detection and quantification of mycotoxins were performed by means of thin layer chromatography (TLC). It is not possible to assure that the intoxication cases observed by the breeders were caused by mycotoxins. However, the aflatoxins present in $7 / 11$ samples and the high levels found in two of them (200 and 300 $\mu \mathrm{g} / \mathrm{kg}$ ) could have been the reason.

\section{INTRODUCTION.}

Mycotoxins are secondary metabolites of filamentous fungi (especially Hyphomycetes), that can be naturally found in food and feedstuffs. So far. over 200 mycotoxins are known. produced by more than 150 different fungi (1.2). However. a relatively small number of mycotoxins have been recognized as natural

\section{RESUMEN}

\section{[Aflatoxinas en alimentos balanceados para conejos]}

Se analizaron 10 muestras de alimentos y una muestra de alfalfa, destinados a la alimentación de conejos, suministradas por plantas procesadoras de la Provincia de Santa Fe, Argentina. Los lotes correspondientes fueron objeto de reclamo por parte de diversos establecimientos de cria y considerados posible causa de intoxicación de los animales. Se investigó el grado y tipo de contaminación fúngica y la presencia de las siguientes micotoxinas en las muestras: aflatoxinas ( $A F l$ ), ocratoxina $A$, citrinina, ácido penicílico, zearalenona (ZEA) y los tricotecenos, toxina T-2, diacetoxiscirpenol (DAS) y deoxinivalenol (DON). El recuento total de hongos se efectuó por el método de dilución en placa con agar dicloran-rosa de bengala-cloranfenicol (DRBC). El aislamiento de especies se realizó en cámara húmeda, sobre agar Aspergillus flavus-parasiticus (AFPA), agar papa-dextrosa-cloranfenicol (PDAC) y agar dicloranglicerol 18\%(DG18). Parala identificación de especies se empleó: agar extracto de malta (MEA), agar Czapekextracto de levadura (CYA), agar papa-dextrosa (PDA) y agar nitrato-glicerol 25\% (G25N). La detección y cuantificación de micotoxinas se efectuó por cromatografia en capa delgada. No es posible asegurar que las intoxicaciones observadas por los criadores hayan sido originadas por micotoxinas. Sin embargo, las aflatoxinas presentes en 7/11 muestras y los altos niveles hallados en dos de ellas (200 y $300 \mu \mathrm{g} / \mathrm{kg}$ ) pudieron ser la causa de las mismas.

contaminants, namely aflatoxins (AFl), ochratoxin $\mathrm{A}$, penicillic acid, and toxins of Fusurium zearalenone (ZEA) and trichothecenes -T-2 toxin, deoxynivalenol (DON). nivalenol (NIV), and diacetoxyscirpenol (DAS)which have occurred most frequently $(14,21,36,38,39)$. Mycotoxicoses diseases caused by mycotoxins- 
includepathological effects and undesirable physiological responses in humans and animals as well, for they affect different organs and tissues. The various toxicity types depend upon dose, organ involved, sex, age and species of the affected animal. They involve acute and chronic effects, hepatotoxicity, nephrotoxicity, hematotoxicity, neurotoxicity, dermatotoxicity, gastrotoxicity, estrogenism, mutagenicity and cancer $(2,20,21,38,39)$. Aflatoxins, which are primarily hepatotoxic, are the most strong among those that are known, and can cause severe effects in laboratory animals after an exposure of even a very low level $(6,20,38)$. On the other hand, longterm research on farm animals, has proved the existence of other phenomena linked to the exposure to most mycotoxins: a decrease of growth rate, reduction of feeding efficiency and immunosupression. All these are important economic factors when considering animal breeding (6).

Since their discovery and up to now, there have been few reports regarding field diseases associated to mycotoxins (20). The most characteristic case was the outbreak linked to aflatoxins, which killed 100,000 turkeys ('Turkey X Disease") in England, in 1960 (1). Some other cases were reported afterwards, related to field diseases induced by aflatoxins in ducklings, swine, calves, dogs and trout (38). In European countries there were nephropaties in swine, induced by ochratoxin A $(19,39)$. Outbreaks linked to T-2 toxin in poultry, horses, livestock and swine, and emetic syndrome in swine associated to DON were reported in USA (39). Estrogenic syndrome in swine and fertility reduction in livestock due to exposure to zearalenone were reported from Europe,USA and Australia (19).

Considering all that has been stated above, rabbit feeds manufactured in Santa Fe, Argentina, were mycotoxicologically analysed. The animals which had been affected, presented hepatic symptoms and a decrease of weight gain. Aflatoxins, ochratoxin A, citrinin, penicillic acid, ZEA, T-2 toxin, DAS and DON were determined in the samples. The mycota present was quantitatively tested and the isolated fungi were identified as regards genus and species. Finally, an association between the potentially toxigenic species and the presence of mycotoxins in the analysed samples was attempted.

\section{MATERIALS AND METHODS}

Ten samples of mixed rabbit feeds and one of dried ground lucern (alfalfa), used as an ingredient, were analysed. Every feeds corresponded to prestarter feed, starter feed, fattening feed and final feed. The samples. were supplied by processing plants from Santa $\mathrm{Fe}$,
Argentina, immediately after manufacturing and marketing, from April to October 1990. They were processed for mycotoxicological analysis between the second and the tenth days following their reception at the laboratory. They were kept at $0^{\circ} \mathrm{C}$ during that period, hermetically, to avoid humidity reabsorption.

\section{a. Sample preparation for mycological analysis:}

a.1. Sample preparation for dilution plating method: Portions of $25 \mathrm{~g}$ were aseptically taken from each of the $500 / 800 \mathrm{~g}$ total weight samples. The first dilution was prepared in $225 \mathrm{ml}$ of $0.1 \%$ aqueous pepto-ne ( $\mathrm{V} /$ v),shaked in a stomacher for 2 minutes at room temperature. Successive dilutions were obtained from this first one, in the same diluent. Aliquots of $0.2 \mathrm{ml}$ were poured, in duplicate, onto the surface of the culture medium respectively, so as to be counted and isolated $(4,17,18)$.

a.2. Sample preparation for direct plating: $25 \mathrm{~g}$ portions of the products were sterilized on surface for 2 minutes by means of $10 \%$ commercial chlorine bleaching agent and washed several times with sterilized distilled water. Sterilized absorbent paper was used to dry the material before pouring it on sterile moist chambers (twolayer strata of cotton + filter paper)

\section{b. Mycological analysis:}

b.1. Total fungal count: Dichloranrose Bengal chloramphenicol agar (DRBC) $(16,28)$ was used. Plates were incubated at $25^{\circ} \mathrm{C}$ for 5 days. Counts were expressed as colony forming units per gram (CFU/g).

\section{b.2. Isolation and identification of species:}

b.2.1. Dilution plating method: Dilutions were poured on chloramphenicol-potato-dextroseagar (PDAC) (17), on Aspergillus flavus-parasiticus agar (AFPA) $(27,28)$, and dichloran-18\% glycerol agar (DG18) (12), the latter being used for the satisfactory isolation of Eurotium species. Plates were incubated at $25^{\circ} \mathrm{C}$ up to the appearance of colonies, i.e. 3 to 5 days. Then they were kept at room temperature $\left(22-27^{\circ} \mathrm{C}\right)$, daylight incidence being permitted so as to favor the formation of reproductive structures.

b.2.2. Direct plating: Material treated with chlorine bleaching was placed on moist chambers mentioned above. Three dishes per sample, were arranged with 5 to 7 particles of material on each one.

The fungi isolated according to the techniques 
stated above were placed on PDA for the identification of Fusarium, related specia and dematiaceous hyphomycetes $(8,23,28,29)$, and on Czapekyeast extract agar (CYA), malt extract agar (MEA) and $25 \%$ glycerolnitrate agar to identify other specia $(7,8,26,28-30)$.

c. Mycotoxin analysis:

Goliñsky et al. multi-method (10) was employed to analyse ochratoxin A, citrinin and penicillic acid. For aflatoxins and $\mathrm{ZEA}$, the $\mathrm{BF}$ modified toluene technique was used, according to the Argentinian IRAM standards (24). To analyse trichothecenes techniques employed were that of Kamimura et al. (15) and that of Trucksess et al. for DON in particular (35). Toxin detection and confirmation was carried out by thin layer chromatography; quantification being made by means of visual comparison against the corresponding reference standards.

\section{RESULTS}

Table 1, shows the outcome of the mycological analysis. Fungal counts range from $9.0 \times 102$ to $3 \times 104$ $\mathrm{CFU} / \mathrm{g}$. Four samples contained a wider diversity of species, some of them considered "field species" (Acremonium strictum, Epicoccum purpurascens, Cladosporium cladosporioides, Phoma eupyrena, Mucor sp.). Aspergillus flavus was isolated from all samples, including the one of dry ground lucern (alfalfa).

From all the analised toxins, only AFl B1 and AFl B2 were detected. Table 2, shows the results of this analysis. Four out of eleven samples were free from aflatoxins in detectable levels. Two samples contained both $\mathrm{AFl} \mathrm{Bl}$ and $\mathrm{AFl} \mathrm{B2}$ in levels ranging from traces to $8 \mu \mathrm{g} / \mathrm{kg}$. Two samples contained AFl B1 in a high level: 200 and $300 \mu \mathrm{g} / \mathrm{kg}$.

Table 1: Total fungal counts and species detected in different categories of rabbit mixed feeds.

\begin{tabular}{|c|c|c|}
\hline Feed & $\begin{array}{l}\text { Total Fungal } \\
\text { Count }(\text { CFU/g) }\end{array}$ & FUNGAL SPECIES \\
\hline 1 & $1,5 \times 10^{3}$ & $\begin{array}{l}\text { Aspergillus flavus Link: Fr, A.terreus Thom; Penicillium duclauxii Delacr.: Acremonium } \\
\text { strictum W. Gams; Epicoccum purpurascens Ehremb. ex Schecht.: Rhizopus stolonifer } \\
\text { (Ehremb. ex Link) Lind; Mucor sp. }\end{array}$ \\
\hline 2 & $9,0 \times 10^{2}$ & A. flavus Link: Fr; Eurotium herbariorum (Wiggers) Link ex Gray. \\
\hline 3 & $10^{3}$ & A. flavus Link: Fr; P. duclatuxii Delacr.; $R$. stolonifer (Ehremb. ex Link) Lind. \\
\hline 4 & $10^{3}$ & A. flavus Link: Fr: P. duclatuxii Delacr.; $R$. stolonifer (Ehremb. ex Link) Lind. \\
\hline 5 & $10^{3}$ & A. flavus Link: Fr; P. duclatuxii Delacr.; $R$. stolonifer, (Ehremb. ex Link) Lind. \\
\hline 6 & $3,0 \times 10^{4}$ & $\begin{array}{l}\text { A. flavus Link: } \mathrm{Fr}, \text { A. terreus Thom; } P \text {. citrinum Thom; Cladosporium cladosporioides (Fres) } \\
\text { de Vries; E. purpurascens Ehremb. ex Schecht.; } \mathbb{R} \text {. stolonifer (Ehremb.ex Link) Lind. }\end{array}$ \\
\hline 7 & $2,0 \times 10^{4}$ & $\begin{array}{l}\text { A. flavus Link: } \mathrm{Fr}, A \text {. terreus Thom, A. niger van Tieghem, A. candidus Link; P. purpuro- } \\
\text { genum Stoll, P. expansum Link ex Gray: A. strictums W. Gams. }\end{array}$ \\
\hline 8 & $10^{4}$ & A. flavus Link: Fr, A. terreus Thom; P. duclauxii Delacr.; R. stolonifer (Ehremb. ex Link) Lind. \\
\hline 9 & $10^{4}$ & A. flavus Link: Fr, A. terreus Thom; P. duclauxii Delacr.; R. stolonifer (Ehremb. ex Link) Lind. \\
\hline 10 & $2,0 \times 10^{3}$ & $\begin{array}{l}\text { A. flavus Link: Fr, A. terreus Thom, A. niger van Tieghem; } P \text {. citrinum Thom; Fusarium } \\
\text { moniliforme Sheldom: A. strictum W. Gams; C. cladosporioides (Fres) de Vries; Phoma } \\
\text { entpyrena Sacc.: R. stolonifer (Ehremb. ex Link) Lind. }\end{array}$ \\
\hline 11 & $10^{3}$ & $\begin{array}{l}\text { A. flav'us Link:Fr; P. citrinum Thom, P. corylophilum Dierckx.; Geotrichum candidum Link } \\
\text { ex Leman: C. cladosporioides (Fres) de Vries; E. amstelodami Mangin. }\end{array}$ \\
\hline
\end{tabular}

Note:

Feeds: 1-3: Pre-starter feed: 4-7: Starter feed: 8-9: Fattening feed: 10: Final feed: 11: Dry ground lucern (ingredient).

$\mathrm{CFU} / \mathrm{g}$ : Colony forming units per gram. 
Table 2: Aspergillus flavus and aflatoxins present in various categories of rabbit feeds.

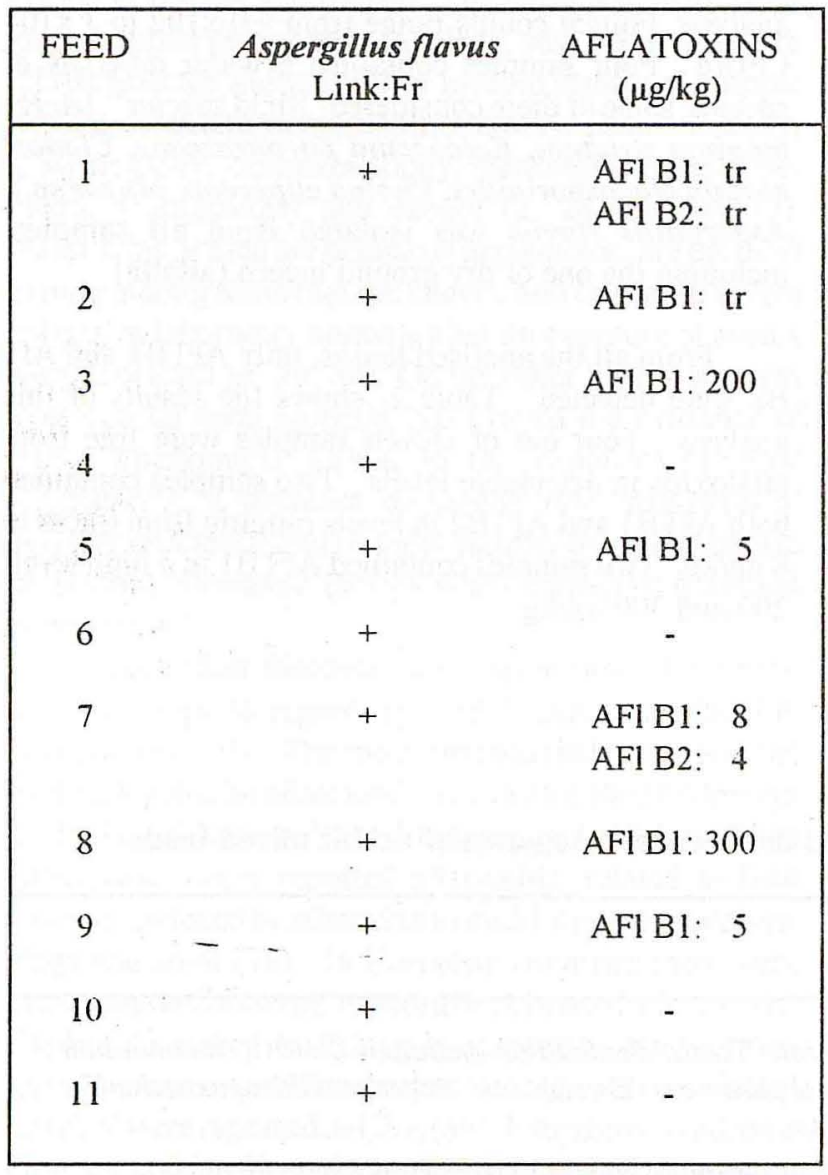

Note:

Feeds: 1-3: Pre-starter feed: 4-7: Starter feed: 8-9: Fattening feed: 10: Final feed: 11: Dry ground lucern.

AF』 B1: aflatoxin B1.. $\mathbb{A} \mid \mathbb{B} 2$ : aflatoxin B2, tr: traces

\section{DISCUSSION}

The huge research work carried out in the USA (1981) and in Polland (1982 and 1985) led scientists to set up warnings regarding fungal counts in mixed animal feeds of $100.000 \mathrm{CFU} / \mathrm{g}(4)$. This figure is taken into account when it refers keeping quality in the commercial sense. However. it can be concluded that when figures represent fungal species with health risk for animals, they are also linked to the biological and nutritional quality of the feeds. The samples examined gave maximum counts of $10^{4} \mathrm{CFU} / \mathrm{g}$. being the level below the standard of reference, but in all of them species of recognized potential toxigenicity . such as Aspergillus and Penicillium species were detected and identified $(5,9,11)$. The only association observed between toxigenic species and their toxins was the simultaneous presence of $A$. flavus and $\mathrm{AFl} \mathrm{B} 1$ and $\mathrm{AFl}$ B2 in 7 and 2 out of 11 samples, respectively. There is a variety of toxic secondary metabolites that can be synthetized in lab cultures by many of the species from the mentioned genera above $(2,5,14,21,31,39)$. However, a precise prediction of their behaviour in food and feeds is not possible. This is due to the fact that these are complex ecosystems influenced by a number of factors namely substratum matricial effect, fungal metabolite interaction (including their synergistic and antagonistic effects) among them and with other organisms, environmental factors (temperature, water activity, $\mathrm{CO}_{2} / \mathrm{O}_{2}, \mathrm{pH}$ ) and the external agents such as pesticides $(3,6,22,32)$.

The presence of $\mathrm{AFl} \mathrm{B1}$ alone, or $\mathrm{AFl} \mathrm{Bl}$ and $\mathrm{B} 2$ in feeds could have caused the symptoms observed in the animals, even when these toxins had been found in trace levels, since rabbits are one of the most sensitive animal. It has been observed that rabbits and ducklings are the most sensitive to the action of aflatoxins. with an oral LD50 of only $0.3 \mathrm{mg} / \mathrm{kg}$ body weight for AFI Bl $(20,38)$.

Taking into account that mycotoxins -especially aflatoxins- can be heterogeneously distributed in feed matrixes (13), it is possible to state the hypothesis that suspicious feeds (those in which aflatoxins were not detected) could have been not conveniently sampled and that the samples taken for the analysis were not representative of the portion eaten by the animals. When food or feed is kept in a wrong way , mainly under humidity and temperature conditions that favour fungal development and the production of mycotoxins, the latter can develop in certain points and not in the total volume of the lot. Some years ago it was proved that these toxins can be found in the fields, when $A$. flavus invades peanut. cottonseeds and corn under certain conditions $(6,18,22,34)$. The bibliography indicates that. even in those products which undergo intensive mixing, the distribution of aflatoxins is heterogeneous enough to allow variations in the contamination levels reach two orders between two different portions of the same lot (25). The presence of $A$. flavus in all of the samples places them in the category of "suspicious feeds". Nowadays, over 40 countries -including the EEC- have current or proposed legislatioon for the regulation of aflatoxins in animal feeds. Several countries (mainly those which need to import raw material or manufactured products) have quite high tolerance levels. These values are almost exclusively applied to certain ingredients of mixed feeds that. in 
turn. must be mixed so as to obtain the final product. Thus. an important reduction of the initial contamination is achieved (from peanut. soya and cotton seeds byproducts. mainly). The type and age of the animals to be fed are also taken into account. In China, the maximum tolerance is of $1,000 \mu \mathrm{g} / \mathrm{kg}$ for total aflatoxins in feedstuff ingredients, with a maximum of $4 \%$ in final products. In Japan, the maximum tolerance is of $1,000 \mu \mathrm{g} / \mathrm{kg}$ of Afl B1 for import peanut meal (maximum: 2 to $4 \%$ of this material in final products). TheEEC accepts a maximum of $200 \mu \mathrm{g} / \mathrm{kg}$ of AFl Bl in certain ingredients. France and Senegal allow $300 \mu \mathrm{g} / \mathrm{kg}$ of $\mathrm{AFlBl}$ in general ingredients and peanut based feedstuffs respectively. Nevertheless. most countries have set a maximum tolerance level ranging from 10 to $50 \mu \mathrm{g} / \mathrm{kgm}$ for both. AFl Bl and the total aflatoxins in final products. exceptions being not higher than $100 \mu \mathrm{g} / \mathrm{kg}(33.37)$. From all that has been stated above. it is considered that AFI B I values of $200 \mu \mathrm{g} /$ $\mathrm{kg}$ in prestarter feed and $300 \mu \mathrm{g} / \mathrm{kg}$ in fattening feed detected in this work are alarming levels. taking into account the fact that they are final products for animal comsumption, especially when these animals are highly susceptible as rabbits are.

\section{ACKNOWLEDGEMENTS}

The authors of present work want to acknowledge Professors Eduardo Piontelli Laforet \& María Alicia Toro Santa María from the Laboratory of Mycology. Universidad de Valparaiso for their valuable assistance in performing taxonomical identification offungal species. They also thank Professor Myriam Ibañez for her painstaking care in translating this paper into English.

\section{REFERENCES}

1.- Asplin, F.D. \& Carnaghan, R.B.A. (1961). The toxicity of certain groundnut meals for poultry with special reference to their effect on ducklings and chickens. Veteriry Records 73: 1215-1218.

2.- Benuet, J.W. (1989). Mycotoxin Research 1989. Mycopathologia 107: $65-66$.

3.- Bullerman, L.B. (1985). Interactive effects of temperature and $\mathrm{pH}$ on Mycotoxin Production. Lebensm. W'iss. Technol. 18: 197-200.

4.- Chelkowski, J. (1991). Mycological quality of mixed feed and ingredients. In: J. Chelkowski (ed.). Cereal Grain. Mycotoxins, Fungi and Quality in Drying and Storage. Elsevier. Amsterdam, pp. 355403.

5.- Cole, R. J. \& Cox, R.H. (eds.). (1981). Handbook of Toxic Fungal Metabolites. Academic Press. USA.

6.- Council for Agricultural Science and Technology. (1989). Mycotoxins: Economic and Health Risks. Task Force Report N ${ }^{\circ} 116$. Ames, Iowa. USA.

7.- Domsch, K.H., Gams, W. \& Anderson T.H. (1980). Compendium of Soil Fungi. Vol. 1. Academic Press Ltd., London.

8. - Ellis, M.B. (1971). Dematiaceous Hyphomycetes. C.A.B.. Commonwealth Mycological Institute. Kew. Surrey. England.

9.- Frisvad, J.C. \& Samson, R.A. (1991). Filamentous fungi in foods and feeds: Ecology: spoilage, and mycotoxin production. In: D.K. Arora. K. G. Mukerji \& E. H. Marth (eds.). Handbook of Applied Mlycology: Vol. 3: Foods and Feeds. Mareel Dekker. Inc.. USA.pp: $31-68$.
10.- Goliñski, P. \& Grabarkiewicz-Czczesna, J. (1984). Chenical confirmatory tests for ochratoxin A, citrinin. penicillic acid, sterigmatocystin, and zearalenone performed directly'onthin layer cluromatographic plates. J. Assoc. Off.Anal.Chem. 67: 1108-1110.

11...-...-..-. (1991). Secondary metabolites (mycotoxins) produced by fungi colonizing cereal grain in storage - structure and properties. In: J. Chelkowski (ed.). Cereal Grain. Mycotoxins. Fungi and Quality in Drying and Storage. Elsevier. Amsterdam. pp. 355-403.

12.- Hocking, A.D. \& Pitt, J.l. (1980). Dichloran-glycerol medium for enumeration of serophilic fungi from low moisture foods. Appl. Environm. Microbiol. 39: 488-492.

13.-Jewer's, K. (1987). Problems in relation to sampling and consiguments for mycotoxin determination and interpretation of results. In: JOINT FAO/WHOUNEP Second International Conference on Mycotoxins. MYC 87'7.1. Bangkok. Thailand.

14.--JofTe, A.Z. (1986). Fus arisum Species: Their Biology and Toxicology Joln Wiley \& Sons. New York.

15.- Kaminura, H., Nishijina, M., Yasuda, K., Saito, K., Ibe, A., Nagayama, T., Ushiyama, H. \& Naoi, Y. (1981). Simultaneous detection of several Fusarium mycotoxins in cereals, grains, and foodstuffs. J.Assoc.Off.Anal.Chem. $64: 1067-1073$.

16.- King, A. D., Hocking, A. D. \& Pitt, J. 1. (1979). Dichoranrose Bengal medium for enumeration and isolation of molds from foods. Appl. Envirom. Microbiol. 37: 959-964. 
17.- King, A. D., Jr., Pitt, J. I., Beuchat, L.R. \& Corry, J.E.L. (eds.). (1986). Methods for the Mycological Examination of Food. Nato ASI Series. Series A: Life Sciences, Vol. 122. Plenum Press. New York.

18.- Klich, M.A. (1986). Presence of Aspergillus flavus in de veloping cotton bolls and its relation to contamination of mature seeds. Appl. Environm. Microbiol. 52: 963-965.

19.- Krogh, P. (1987). Ochratoxins in food. In: P.Krogh (ed.), Mycotoxins in Food. Acadenic Press, London, pp. 97-121.

20.--.-.-. (1989). The role of mycotoxins in disease of animals and man. In: M.O. Moss, B. Jarvis \& F.A. Skinner (eds.), Filamentous Fungi in Foods and Feeds. The Society for Appl.Bacteriol. Symposium Series No.18: 99S-104S.

21.- Kurata, H. \& Ueno, Y. (eds.). (1984). Toxigenic Fungi . Their Toxins and Health Hazard. Elsevier, Ansterdam.

22.- Lacey, J. (1989). Pre- and post-harvest ecology of fungi causing spoilage of foods and other stores produets. In: In: M.O. Moss, B. Jarvis \& F. A. Skinner (eds.). Filamentous Fungi in Foods and Feeds. The Society for Appl.Bacteriol. Symposium Series No.18: $11 \mathrm{~S}-25 \mathrm{~S}$.

23.- Nelson, P.E., Toussoun, T.A. \& Marasas, W.F.O. (1983). Fusarium species. An Illustrated Manual for Identification. The Pennsylvania State University Press, USA.

24.- Norma IRAM 1 4803. (1990). Método de determinación de aflatoxinas y zearalenona en maiz y mani. Instituto de Racionalización de Materiales. Argentina.

25.- Park, D.L. \& Pohland, A.E. (1989). Sampling and sample preparation for detection and quantitation of natural toxicants in food and feed. J.Assoc.Oft.-Anal.Chem. 72: 399-404.

26.- Pitt, J.I. (1979). The Genus Penicillium and its teleomorphic states Eupenicillium and Talaromyces. Academic Press Inc., Ltd., London.

27.- ------, Hocking, A.D. \& Glenn, D.R. (1983). An improved medium for the detection of Aspergillus flasus and Aspergillus parasisicats. J. Appl. Bacteriol. 54: 109-114.
28.-

Press, Australia:

(1985). Fungi and Food Spoil age. Academic

29.- Raper, K. B. \& Fennel, D. I. (1965). The Genus Aspergillus. The Willians \& Wilkins Co., Baltimore, USA.

30.- Samson, R.A. \& Pitt, J.I. (eds.). (1985). Advances in Penicillium and Aspergillus Systematics. Plenum Press, New York and London, Published in Cooperation with NATO Scientific Affairs Division.

31.- Scott, P.M. (1983). Other mycotoxins. In: Proceedings of the International Symposium on Mycotoxins. FDA. Maryland, and National Research Centre, Cairo, Egypt.

32.--_--.-. (1991). Possibilities of reduction or elimination of mycotoxins present in cereal grains. In: J. Chelkowski (ed.), Cereal Grain. Mycotoxins, Fungi and Quality in Drying and Storage. Elsevier, Ansterdam, pp. 529-572.

33.- Stolof, L., Van Egmond, H.P. \& Park, D.L. (1991). Rationales for the establishment of limits and regulation for mycotoxins. Food Additives and Contaminants $8: 213-222$

34.- Takahashi, H. Yazaki, H. \& Ichinoe, M. (1984). Mycoflora and mycotoxin potential of domestic peanuts. J. Antibact. Antifung. Agents 12: 429-436.

35.- Trucksess, M.W., Flood, M.T. \& Page, S.W. (1986). Thin layer chromatographic determination of deoxynivalenol in processed grain products. J.Assoc.Off.Anal.Chem. $69: 35-36$.

36.- Ueno, Y. (1986). Trichothecenes as envirommental toxicants. In: E. Hodgson (ed.), Reviews in Environmental Toxicology 2. Elsevier, Amsterdam, pp. 303-341

37.- Van Egmond, H. P. (1989). Current situation on regulations for mycotoxins. Overview of tolerances and status of standard methods of sampling and analysis. Food Additives and Contaminants 6 : 139-188.

38.- W. H. O. (World Health Organization). (1979). Mycotoxins. Environmental Health Criteria $N^{\circ} 11$, Geneva.

39.-- (1990). Selected Mycotoxins: Ochratoxins, Trichothecenes, Ergot. Environmental Health Criteria 105. Geneva. 